\title{
Ecology of epiphyllous stages of endophytes and implications for horizontal dissemination
}

\author{
M. TADYCH and J.F. WHITE, JR. \\ Department of Plant Biology and Pathology, Rutgers University, New Brunswick, NJ 08901, USA \\ tadych@aesop.rutgers.edu
}

\begin{abstract}
Experiments were conducted to examine aspects of the ecology of the epiphyllous stage of a Neotyphodium endophyte on leaves of Poa ampla (big bluegrass) plants. Conidia were found to be readily water dispersed and to survive for several weeks on leaf surfaces. Neotyphodium was found to colonise excised grass leaves and grow on growing meristems of seedlings. The significance of epiphyllous stages of endophytes was also evaluated and discussed.

Keywords: Clavicipitaceae, Neotyphodium, conidia,dissemination, water dispersal, endophytes, epiphytes, epiphyllous, big bluegrass, Poa ampla

\section{Introduction}

It is generally believed that Neotyphodium endophytes are limited to internal tissues of grass plants, including leaves, culms, ovules, and seeds. However, some Neotyphodium endophytes have been shown to emerge from plants and produce a network of mycelium and conidia on the surfaces of plants. This epiphyllous mycelium is most pronounced on leaf blades of certain species of Pooideae, including the bent grasses, fescues, forest hedgehog grass, ryegrasses, wild barley, and some blue grasses (White et al. 1996; Christensen et al. 1997; Moy et al. 2000; Craven et al. 2001; Dugan et al. 2002; Moon et al. 2002). Nothing is currently known regarding the ecology or implications of production of the epiphyllous conidial stages in the life cycles of endophytes.
\end{abstract}

\section{Materials and Methods}

\section{Plant and fungal material}

Poa ampla Merr. (big bluegrass) infected by a Neotyphodium sp., was chosen for study. The plants were collected from sites along the Alaska Highway in Yukon, Canada and maintained in the Rutgers University Research Greenhouse Facility, in New Brunswick, New Jersey. Neotyphodium sp. used in this study was isolated by the leaf wash method from the leaf surfaces of P. ampla. Voucher material of the fungus is preserved as a living culture in $20 \%$ glycerol at $-80^{\circ} \mathrm{C}$ freezer in the Rutgers University Plant Pathology Herbarium (RUTPP) at School of Environmental and Biological Sciences, Rutgers University.

\section{Examination of the epiphyllous stage}

Leaves of $P$. ampla were examined to demonstrate the presence of epiphyllous mycelium using the acetate peel procedure (White et al. 1996). The peels were examined for occurrence of fungal structures using a Nikon Labophot-2 compound light microscope (150-600x).

\section{Spore deposition experiments}

Nine plants of endophyte-infected $P$. ampla with developed epiphyllous stages of Neotyphodium sp. growing under greenhouse conditions were randomly selected for an experiment to evaluate the possibility of spore deposition from the leaf surface of plants by gravity force. From each plant, five young, completely developed leaves were randomly selected and investigated by the spore fall technique. For each leaf an individual Petri dish with Potato Dextrose Agar (Difco) amended with $20 \mathrm{mg} / \mathrm{L}$ penicillin and $40 \mathrm{mg} / \mathrm{L}$ streptomycin sulfate $(\mathrm{PDA}+2)$ as a trap plate was used. A selected living leaf was placed into the trap plate on the surface of a coarse mesh positioned $2 \mathrm{~mm}$ above the medium level. The mesh supported the leaf avoiding direct contact with the medium. After $24 \mathrm{~h}$ the leaf was removed from the plate. Precautions were taken to avoid touching the medium or plate's wall by the leaf while inserting it into, or removing it from, the plate. Then the plates were transferred to the laboratory and incubated in the dark at $22^{\circ} \mathrm{C}$ for several days. As organisms developed on plates, they were transferred into a new plate with PDA or other appropriate medium and subcultured. All developed organisms were counted and identified to genus or species level based on their morphological features. The fungi were identified using taxonomic keys: Aspergillus spp. (Klich \& Pitt 1988), Penicillium spp. (Pitt 1998), yeast (Barnett et al. 2000), and other fungi (Domsch et al. 1993; Gams 1971).

\section{Spore dissemination experiments}

To evaluate potential for water dispersal vs. air dispersal an experiment was conducted using water spray, water vortex, and air currents. Here 10 leaves ( $c a .8 \mathrm{~cm}$ long) were treated as follows: 1) sprayed with sterile distilled water until water dripped off onto a sterile Petri dish; 2) vortexed in sterile distilled water for 20 seconds or 3) subjected to a stream of filtered air with $\mathrm{PDA}+2$ plate placed directly under leaves. In treatments 1 and 2 water $(0.3 \mathrm{ml})$ from leaf washes was then spread onto PDA+2 plate. During a period of 2-8 days all fungi emerging were examined and identified.

\section{Seedling colonisation experiments}

Studies were conducted to evaluate the potential for the Neotyphodium endophyte from conidia to grow on the surfaces of seedlings. In this experiment, seeds were heat-treated (Bouton et al. 1993) to destroy the fungal endophyte in seeds and surface-sterilised with sodium hypochlorite. Then seeds were planted into plates with sterile water agar. After germination of seeds, the seedlings were microscopically examined for any epiphyllous fungal structures growing on the seedlings. Conidia from Neotyphodium culture were suspended in sterile distillated water and four drops of water-spore suspension with an average of 132600 spores of Neotyphodium were placed on each seedling. Seedlings were then monitored for epiphyllous conidial production over a period of 3 months using a Nikon Labophot-2 compound light microscope (60-150x). Photographs of the fungal structures were obtained with a Nikon 4300 digital camera.

\section{Excised leaf colonisation study}

An experiment to evaluate the capability of Neotyphodium to grow on excised and sterilised leaves of $P$. ampla was performed. In this experiment, young fully developed leaves of $P$. ampla were excised and sterilised. Then approximately $70 \mathrm{ml}$ of artificial (2 portions of vermiculite, 1 portion of clay and 0.5 portion of sand) and sterilised soil was placed in 250-ml glass beaker and coated 
by $0.36 \mathrm{~g}$ (fresh weight) of excised leaves. Subsequently, 0.75 $\mathrm{ml}$ of water-spore suspension of Neotyphodium (an average of 11700 spores) was spread on the surface of leaves and soil. The beaker was covered with plastic film and placed on a laboratory shelf with continuous fluorescent lights. The control was treated with $0.75 \mathrm{ml}$ of sterile distillated water. After 14 days, endophytefree seedlings of $P$. ampla were placed in each beaker. Growth of fungal structures on the surface of soil, plant debris and adjusted seedlings was monitored. Photographs of the fungal structures growing on the plant debris of $P$. ampla were obtained with a Nikon 4300 digital camera.

\section{Conidial viability study}

Neotyphodium sp. isolated form leaf surfaces of $P$. ampla was plated on PDA+2 medium. After 2-5 days, typically slowgrowing colonies of Neotyphodium sp. were transferred onto fresh PDA plates without antibiotics and incubated for 14 days. The cultures then were used to make a spore suspension with sterile distillated water. A $2 \%$ agar block of PDA ( $25 \times 30 \times 3-4$ $\mathrm{mm})$ was placed on a glass slide. A suspension of conidia (0.03 ml) was then uniformly spread on the agar block. This slide culture was placed inside the sterile Petri dish and incubated in the dark at $22^{\circ} \mathrm{C}$ for 16 days. After 16 days of growth, the cultures were dried out. To dry the cultures, they were placed under an operating laminar flow hood with blowing air at $22^{\circ} \mathrm{C}$ for $60 \mathrm{~h}$. After drying, all cultures were again inserted into sterile plates and wrapped with parafilm. The cultures (in three replicates) were randomly divided into three groups and each group was placed in the dark at different temperatures, i.e. 10,20 or $30^{\circ} \mathrm{C}$ with relative humidity $(\mathrm{RH})$ below $45 \%$. At week $1,2,4$, and 8 after drying, a direct impression of the upper surface of the culture was made onto a fresh plate with PDA medium. The plate with the impression was incubated in the dark at $22^{\circ} \mathrm{C}$. Viability of conidia was examined $24 \mathrm{~h}$ later. Evaluation was made based on eight pictures taken from equidistant areas of each impression. Examination was performed with an Olympus BX41 compound light microscope equipped with an Olympus MagnaFire 2.0 digital camera connected to a PC running MagnaFire 2.0 camera software (Optronics, Goleta, CA). Pictures were taken at equal exposure times for each culture at $250 \mathrm{x}$ magnification. Data were analysed based on an average of germinated spores per $1 \mathrm{~mm}^{2}$ with standard deviation.

\section{Results and Discussion}

\section{Epiphyllous fungi}

The surfaces of leaves (phylloplanes) were seen to bear typical Neotyphodium mycelium and conidia, and mycelia and conidia of several other species. In the initial experiment, conducted to evaluate fungal conidia that were released from leaves through gravity force of spore deposition through air, 23 fungal species were obtained (Table 1). The fungi most frequently isolated in this gravity experiment were Cladosporium cladosporioides (29.7\%), Acremonium strictum and mycelia sterilia (9.9\%), and the yeast Pseudozyma sp. (14.4\%); Neotyphodium was isolated only twice $(1.8 \%)$.

Spores of Cladosporium cladosporioides are common on the aerial surface of many higher plants throughout temperate regions (Dickinson 1971; Lee \& Hyde 2002). Our study confirmed earlier studies of Di Menna (1971), Tolstrup \& Smedegaard-Petersen (1984), Smedegaard-Petersen \& Tolstrup (1985) and Moy et al. (2000) showing that Cladosporium species usually dominate among the filamentous fungi inhabiting leaf surfaces of Poaceae. The present study also revealed several species of yeasts. Yeasts are important part of leaf microflora and they have been isolated from phylloplanes of other grasses (Di Menna 1971; Tolstrup \& Smedegaard-Petersen 1984; Smedegaard-Petersen \& Tolstrup 1985; Middelhoven 1997). Among them Pseudozyma sp. was the most commonly isolated genus. Species of this genus are anamorphs of smut fungi of Ustilago that parasitise grasses (Begerow et al. 2000; Fell et al. 2000). Acremonium strictum is the most common species of the genus (Domsch et al. 1993). This species can be considered as a secondary invader, endophyte or pathogen of host plants (Gams 1971; McGee et al. 1991; Tagne et al. 2002). The experiment also revealed two colonies of Neotyphodium. It is more likely that these spores were transferred from the leaf surface by drops of water. Drops of water can move developed spores from the leaf surface onto the medium (Fitt \& McCartney 1986). During the $24 \mathrm{~h}$ experiment condensation of water was observed on the inner surfaces of plates.

\section{Spore dissemination}

In the experiment to evaluate potential for water dispersal $v s$. air dispersal, water treatments resulted in numerous isolations of Neotyphodium while no colonies of Neotyphodium resulted from air treatments (Table 2). Data are summarised as follows: vortex - an average of 42 colonies of Neotyphodium per plate, spray - an average of 35.3 colonies of Neotyphodium per plate, and air - no Neotyphodium resulted.

Table 1 Frequency of fungi isolated from leaves of Poa ampla by the spore deposition method.

\begin{tabular}{lc}
\hline Fungus & Frequency (\%) \\
\hline Acremonium implicatum & 1.8 \\
Acremonim strictum & 9.9 \\
Actinomycetes sp. & 2.7 \\
Aspergillus fumigatus & 0.9
\end{tabular}

Basidiomycetes sp. $\quad 2.7$

Candida sp.

Cladosporium cladosporioides

Fellomyces sp.

Geniculosporum sp.

Geotrichum candidum

Mycelia sterilia

Neotyphodium sp.

Nigrospora sphaerica

Oidiodendron sp.

Penicillium citrinum

Penicillium implicatum

Penicillium minioluteum

Pseudozyma sp.

Rhinocladiella sp.

Rhodotorula sp.

Streptomyces sp.

Trichoderma harzianum

Torula sp. 
Table 2 Average number of fungal spores released from Poa ampla leaf surfaces using air or water.

\begin{tabular}{llcc}
\hline Fungus & Air & Vortex & Spray \\
\hline Acremonium sp. & 0.0 & 1.3 & 0.3 \\
Cladosporium sp. & 4.3 & 13.3 & 6.7 \\
Mycelia sterilia & 2.0 & 0.7 & 1.3 \\
Neotyphodium sp. & 0.0 & 42.0 & 35.3 \\
Penicillium sp. & 0.0 & 0.3 & 0.0 \\
Torula sp. & 0.3 & 0.3 & 0.0 \\
Yeasts & 0.3 & 2.0 & 0.3 \\
\hline
\end{tabular}

Figure 1 Neotyphodium sp.: A. Hyphae (h) producing conidiophores (cp) and conidia (c) on the leaf surface (L) of Poa ampla seedling. B. Conidiophores (cp) and conidia (c) on the leaf (L) of Poa ampla. C. Mycelium (m) growing on sterilised leaf parts of Poa ampla - 14 days after inoculation. D. Mycelium $(\mathrm{m})$ growing on the debris of plant covering soil in pot with Poa ampla seedlings -36 days after inoculation.

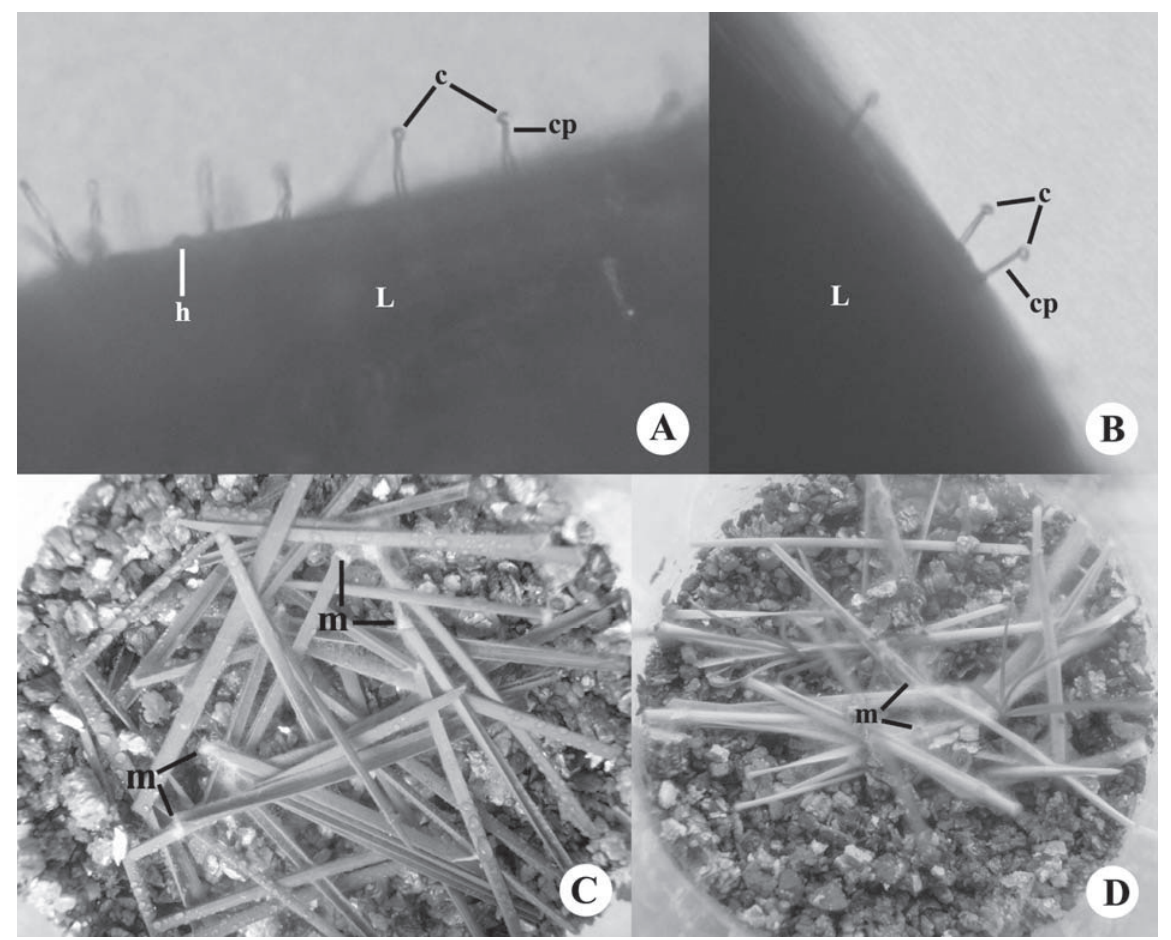

Figure 2 Germination of spores of Neotyphodium sp. after drying and storing at 3 different temperatures.

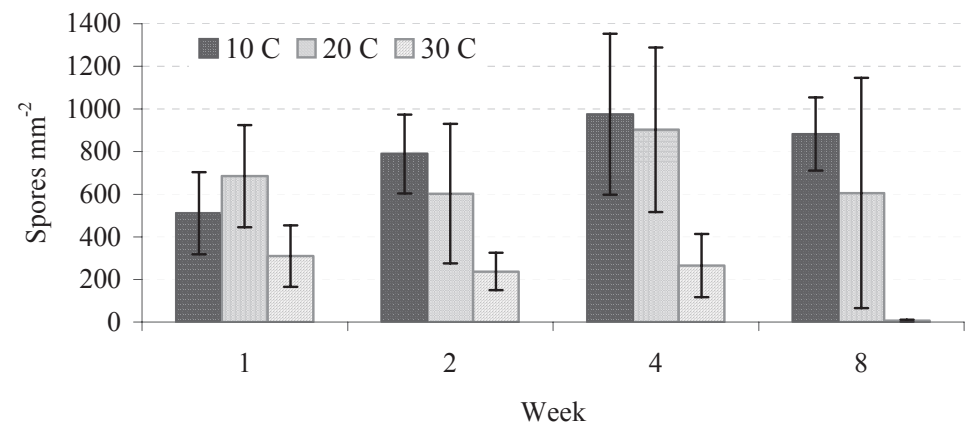


Grass endophytic fungi (Neotyphodium sp.) that produce no stromata on plants are believed to be incapable of horizontal transmission and the infected seeds are thought to be the only mode of propagation (Bacon \& Siegel 1988; Clay 1988; Schardl et al. 1994). However, it has been hypothesised that the endophytic fungus may posses the ability for horizontal transfer from plant to plant via conidia produced from epiphyllous mycelium on the host epidermis (White et al. 1996). This experiment suggests that epiphyllous conidia of Neotyphodium are likely to be water dispersed rather than air dispersed. Asexual spores of many fungal species from the order Hypocreales have been documented as being water disseminated (Chaverri \& Samuels 2003; Sutton 1980; Webster 1980). It has been hypothesised that epiphyllous conidia might be responsible for distribution of Neotyphodium tembladerae in multiple grass species in South America, and multistrain infection of a single grass plant, Brachypodium sylvaticum by Epichloë sylvatica (Cabral et al. 1999; Meijer \& Leuchtmann 1999). Presence of the epiphyllous mycelia and conidia of asexual endophytes on the surfaces of some grass species might also facilitate hybridisation, and transfer of genes between Neotyphodium/Epichloë species may occur epiphytically. According to Schardl et al. (1994), Tsai et al. (1994), Chung \& Schardl (1997), and Schardl \& Craven (2003), hybridisation by somatic fusion of endophyte hyphae could occur between Epichloë species. Recent studies showed that several asexual grass endophytes arose from such hybridisation (Moon et al. 2000, 2002, 2004).

\section{Seedling colonisation}

Experiments were conducted to evaluate the potential for Neotyphodium endophytes from conidia to grow on the surfaces of seedlings. Seedlings inoculated with Neotyphodium conidia were colonised rapidly by the endophyte and demonstrated epiphyllous production of conidiogenus cells and conidia that were concentrated on the base of leaves near basal meristems and along the leaf marginal meristems (Figs. 1A \& B).

The meristematic tissues of the plant are less developed with thin epidermal and cuticle barrier layers. It is probable that nutrients are emerging to the plant surface at these meristematic regions and fueling epiphyllous development. The present study confirmed the observation of Meijer \& Leuchtmann (1999). These authors observed that Epichloë sylvatica grows out of the seed and sporulates on the surfaces of seedlings of Brachypodium sylvaticum during germination on water agar.

\section{Excised leaf colonisation}

In these experiments we evaluated the capability for Neotyphodium to grow on excised and sterilised leaves of $P$. ampla. Here we found that Neotyphodium was capable of growing and sporulating on dead leaves (Figs. 1C \& D), suggesting the potential to spread via conidia on dead or dying leaves to surfaces of adjacent plants. We are not aware of other studies that demonstrate that Neotyphodium endophytes have saprophytic capabilities.

\section{Conidial viability}

To evaluate the capacity of conidia of Neotyphodium to survive epiphyllously, a conidial viability study was conducted. Here it was shown that spores of Neotyphodium could survive for at least 1 month under all conditions (Fig. 2). This suggests that conidia on leaf surfaces may survive at least this period of time. No other research has been conducted on survival of Neotyphodium spores. However, it has been shown that survival of the Neotyphodium endophyte in seed is dependent on length of storage and storage temperature, as well as seed moisture content (Bacon \& Siegel 1988). Endophyte viability decreased to zero after 48 weeks of storage at $21^{\circ} \mathrm{C}$, but remained at greater than $80 \%$ at lower temperatures (Siegel et al. 1984). Endophyte viability remained high for the 117 weeks of the experiment at $-20^{\circ} \mathrm{C}$ and $6^{\circ} \mathrm{C}$ storage temperatures. However, at $10^{\circ} \mathrm{C}$, viability gradually decreased to $30 \%$. Indeed, storage at $0-5^{\circ} \mathrm{C}$ and $25-50 \%$ RH has been reported to preserve the viability of Neotyphodium lolii in perennial ryegrass seed for up to 7 years (Latch \& Christensen 1982).

\section{Conclusions}

The results that we have obtained suggest a model for dissemination of endophytes employing epiphyllous conidia. Conidia may be produced on surfaces of grasses and/or dead leaves, and spread via water currents, rain splash or drip splash to adjacent plants. It is likely that epiphyllous growth of the endophyte is stimulated in the regions of meristematic activity of the grass. It seems reasonable that endophytic infections of grasses may occur in these meristematic regions where nutrients are abundant and cuticular barriers are minimal or lacking. Future studies are needed to experimentally evaluate this proposed mechanism of host infection by endophytes.

\section{ACKNOWLEDGEMENTS}

This study was supported by the National Institutes of Health - Fogarty International Center with the International Cooperative Biodiversity Groups grant. We are also grateful to Dr. Marshall Bergen for laboratory assistance.

\section{REFERENCES}

Bacon, C.W.; Siegel, M.R. 1988. Endophyte parasitism of tall fescue. Journal of Production Agriculture 1: 45-55.

Barnett, J.A.; Payne, R.W.; Yarrow, D. 2000. Yeasts: Characteristics and Identification. $3^{\text {rd }}$ ed. Cambridge University Press, Cambridge. $1139 \mathrm{pp}$.

Begerow, D.; Bauer, R.; Boekhout, T. 2000. Phylogenetic placements of ustilaginomycetous anamorphs as deduced from nuclear LSU rDNA sequences. Mycological Research 104: 53-60.

Bouton, J.H.; Gates, R.N.; Belesky D.P.; Owsley M. 1993. Yield and persistence of tall fescue in the Southeastern Coastal Plain after removal of its endophyte. Agronomy Journal 85: 52-55.

Cabral, D.; Cafaro, M.J.; Saidman, B.; Lugo, M.; Reddy, P.V.; White, J.F., Jr. 1999. Evidence supporting the occurrence of a new species of endophyte in some South American grasses. Mycologia 91: 315-325.

Chaverri, P.; Samuels, G.J.; 2003. Hypocrea/Trichoderma (Ascomycota, Hypocreales, Hypocreaceae): species with green ascospores. In: Studies in Mycology 48. Centraalbureau voor Schimmelcultures, Baarn.

Christensen, M.J.; Ball, O.J-P.; Bennet, R.J.; Schardl, C.L. 1997. Fungal and host genotype effects on compatibility and vascular colonization by Epichloë festucae. Mycological Research 101: 493-501.

Chung, K-R.; Schardl, C.L. 1997. Vegetative compatibility between and within Epichloë species. Mycologia 89: 558-565.

Clay, K. 1988. Clavicipitaceous fungal endophytes of grasses: coevolution and the change from parasitism to mutualism. pp. 79-105. In: Coevolution of fungi with plants and animals. Eds. Pirozynski, K.A.; Hawksworth, D. Academic Press, London.

Craven, K.D.; Blankebship, J.D.; Leuchtmann, A.; Hignight, K.; Schardl, C.L. 2001. Hybrid fungal endophytes symbiotic with the grass Lolium pretense. Sydowia 53: 44-73. 
Dickinson, C.H. 1971. Cultural studies of leaf saprophytes. pp. 129-137. In: Ecology of leaf surface micro-organisms. Eds. Preece, T.F.; Dickinson, C.H. Academic Press, New York.

Di Menna, M.E. 1971. The mycoflora of leaves of pasture plants in New Zealand. pp. 159-174. In: Ecology of leaf surface micro-organisms. Eds. Preece, T.F.; Dickinson, C.H. Academic Press, New York.

Domsch, K.H.; Gams, W.; Anderson, T-H. 1993. Compendium of soil fungi. Vol. 1. IHW-Verlag, Eching. 860 pp.

Dugan, F.M.; Sitton, J.W.; Sullivan, R.F.; White, J.F., Jr. 2002. The Neotyphodium endophyte of barley (Hordeum brevisubulatum subsp. violaceum) grows and sporulates on leaf surfaces of the host. Symbiosis 32: 147-159.

Fell, J.W.; Boekhout, T.; Fonseca, A.; Scorzetti, G.; StatzellTallman, A. 2000. Biodiversity and systematics of basidiomycetous yeasts as determined by large-subunit rDNA D1/D2 domain sequence analysis. International Journal of Systematic and Evolutionary Microbiology 50: 1351-1371.

Fitt, B.D.L.; McCartney, H.A. 1986. Spore dispersal in splash droplets. pp 87-104. In: Water, Fungi and Plants: symposium of the British Mycological Society held at the University of Lancaster, April 1985. Eds. Ayres, P.G.; Boddy, L. Cambridge University Press/The Bath Press, Avon.

Gams, W. 1971. Cephalosporium-artige Schimmelpilze (Hyphomycetes). Gustav Fischer Verlag, Stuttgart. 262 pp.

Klich, M.A.; Pitt, J.I. 1988. A laboratory guide to common Aspergillus species and their teleomorphs. Commonwealth Scientific and Industrial Research Organization, Division of Food Processing, North Ryde. 116 pp.

Latch, G.C.M.; Christensen, M.J. 1982. Ryegrass endophyte, incidence, and control. New Zealand Journal of Agricultural Research 25: 443-448.

Lee, O.H.K.; Hyde, K.D. 2002. Phylloplane fungi in Hong Kong mangroves: evolution of study methods. Mycologia 94: 596-606.

McGee, P.A.; Hincksman, M.A.; White, C.S. 1991. Inhibition of growth of fungi isolated from plants by Acremonium strictum. Australian Journal of Agricultural Research 42: 1187-1193.

Meijer, G.; Leuchtmann, A. 1999. Multistrain infections of the grass Brachypodium sylvaticum by its fungal endophyte Epichloë sylvatica. New Phytologist 141: 355-368.

Middelhoven, W.J. 1997. Identity and biodegradative abilities of yeasts isolated from plants growing in an arid climate. Antonie van Leeuwenhoek 72: 81-89.

Moon, C.D.; Scott, B.; Schardl, C.L.; Christensen, M.J. 2000. The evolutionary origins of Epichloë endophytes from annual ryegrasses. Mycologia 92: 1103-1118.

Moon, C.D.; Miles, C.O.; Järlfors, U.; Schardl, C.L. 2002. The evolutionary origins of the three new Neotyphodium endophyte species from grasses indigenous to the Southeren Hemisphere. Mycologia 94: 694-711.

Moon, C.D.; Craven, K.D.; Leuchtmann, A.; Clement, S.L.; Schardl, C.L. 2004. Prevalence of interspecific hybrids amongst asexual fungal endophytes of grasses. Molecular Ecology 13: 1455-1467.

Moy, M.; Belanger, F.; Duncan, R.; Freehoff, A.; Leary, C.; Meyer, W.R.; Sullivan, R.; White, J.F., Jr. 2000. Identification of epiphyllous mycelial nets on leaves of grasses infected by Clavicipitaceous endophytes. Symbiosis 28: 291-302.

Pitt, J.I. 1998. A laboratory guide to common Penicillium species. Commonwealth Scientific and Industrial Research Organization, Division of Food Processing, North Ryde. 187 pp.

Schardl, C.L.; Craven, K.D. 2003. Interspecific hybridization in plant-associated fungi and oomycetes: a review. Molecular Ecology 12: 2861-2873.

Schardl, C.L.; Leuchtmann, A.; Tsai, H-F.; Collett, M.A.; Watt, D.M.; Scott, D.B. 1994. Origin of a fungal symbiont of perennial ryegrass by interspecific hybridization of a mutualist with the ryegrass choke pathogen, Epichloë typhina. Genetics 136: 1307-1317.

Siegel, M.R.; Varney, D.R.; Johnson, M.C.; Nesmith, W.C.; Buckner, R.C.; Bush, L.P.; Barruss, II, P.B.; Hardison, J.R. 1984. A fungal endophyte of tall fescue: evaluation of control methods. Phytopathology 74: 937-941.

Smedegaard-Petersen, V.; Tolstrup, K. 1985. The limiting effect of disease resistance on yield. Annual Review of Phytopathology 23: 475-490.

Sutton, B.C. 1980. The Coelomycetes: fungi imperfecti with pycnidia, acervuli and stromata, $1^{\text {st }}$ ed. Commonwealth Mycological Institute, Kew, Surrey. 696 pp.

Tagne, A.; Neergaard, E.; Hansen, H.J.; The, C. 2002. Studies of host-pathogen interaction between maize and Acremonium strictum from Cameroon. European Journal of Plant Pathology 108: 93-102.

Tolstrup, K.; Smedegaard-Petersen, V. 1984. Saprophytic leaf fungi on barley and their effect on leaf senescence and grain yield. Växtskyddsnotiser 48: 66-75.

Tsai, H-F.; Liu, J-S.; Staben, C.; Christensen, M.J.; Latch, G.C.M.; Siegel, M.R.; Schardl, C.L. 1994. Evolutionary diversification of fungal endophytes of tall fescue grass by hybridization with Epichloë species. Proceedings of the National Academy of Sciences of the United States of America 91: 2542-2546.

Webster, J. 1980. Introduction to Fungi, $2^{\text {nd }}$ ed. Cambridge University Press, Cambridge. 669 pp.

White, J.F., Jr.; Martin, T.I.; Cabral, D. 1996. Endophytehost associations in grasses. XXII. Conidia formation by Acremonium endophytes on the phylloplanes of Agrostis hiemalis and Poa rigidifolia. Mycologia 88: 174-178. 